RNA 21: 1219-1232 (2015)

\title{
Corrigendum: Conserved RNA secondary structures and long-range interactions in hepatitis $\mathrm{C}$ viruses \\ MARKUS FRICKE, NADIA DÜNNES, MARGARITA ZAYAS, RALF BARTENSCHLAGER, MICHAEL NIEPMANN, and MANJA MARZ
}

In the above-noted article, the Acknowledgments section was incomplete and should instead read as follows:

"This work was in part funded by Deutsche Forschungsgemeinschaft (DFG) projects MA-5082/1, NI-604/2-2, SPP 1596, IRTG 1384, SFB 1021, and the Carl-Zeiss-Stiftung."

This article has been corrected in both the PDF and full-text HTML files online.

doi: $10.1261 /$ rna.058123.116

RNA 22: 96-110 (2016)

\section{Corrigendum: Long-range RNA pairings contribute to mutually exclusive splicing YUAN YUE, YUN YANG, LANZHI DAI, GUOZHENG CAO, RAN CHEN, WEILING HONG, BAOPING LIU, YANG SHI, YIJUN MENG, FENG SHI, MU XIAO, and YONGFENG JIN}

In the Discussion section (first paragraph, third sentence) on page 105 of the above-noted article, the sentence "The RNA architectures identified in our study were not predicted by in silico approaches (Pervouchine 2014), nor were they detected using recent high-throughput RNA structure sequencing techniques (Daines et al. 2011; Li et al. 2012)" was not clear and should instead read as follows: "The RNA bidirectional structural architectures identified in our study were not detected using recent high-throughput RNA structure sequencing techniques (Daines et al. 2011; Li et al. 2012), nor were they discovered by in silico approaches, although stem II of the Drosophila srp pre-mRNA was predicted (Raker et al. 2009; Pervouchine 2014).”

Accordingly, the following reference should be included in the References section:

Raker VA, Mironov AA, Gelfand MS, Pervouchine DD. 2009. Modulation of alternative splicing by long-range RNA structures in Drosophila. Nucleic Acids Res 37: 4533-4544.

The authors apologize for any confusion this may have caused.

This article has been corrected in both the PDF and full-text HTML files online.

doi: $10.1261 /$ rna.058008.116 

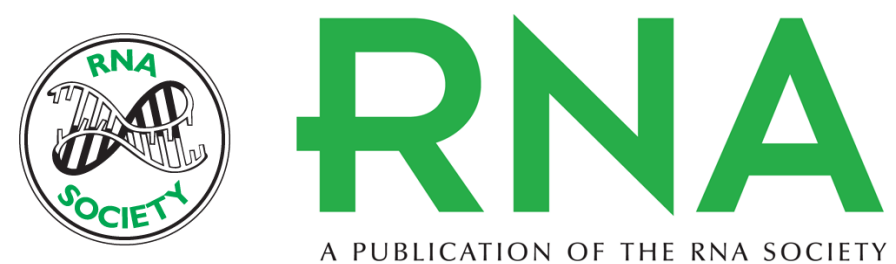

A PUBLICATION OF THE RNA SOCIETY

\section{Corrigendum: Conserved RNA secondary structures and long-range interactions in hepatitis $\mathrm{C}$ viruses}

Markus Fricke, Nadia Dünnes, Margarita Zayas, et al.

RNA 2016 22: 1640.1

\section{Related Content Conserved RNA secondary structures and long-range interactions in hepatitis C viruses \\ Markus Fricke, Nadia Dünnes, Margarita Zayas, et al. \\ RNA July , 2015 21: 1219-1232 \\ Open Access Freely available online through the RNA Open Access option. \\ License \\ Email Alerting Receive free email alerts when new articles cite this article - sign up in the box at the Service top right corner of the article or click here.}

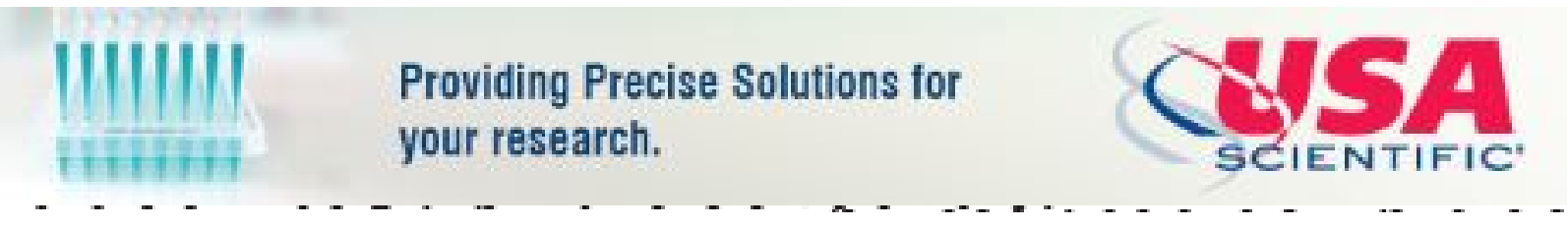

To subscribe to $R N A$ go to:

http://rnajournal.cshlp.org/subscriptions

Published by Cold Spring Harbor Laboratory Press for the RNA Society 